CUAJ honours its members and friends who have passed away. We invite colleagues of the deceased to submit brief remembrances. Please limit your notice to 200 words. Send your notice to journal@cua.org or fax it to 514-395-1664.
Cite as: Can Urol Assoc J 2018;12(8):287. http://dx.doi.org/10.5489/cuaj.5417

\section{Dr. Edward Lee Johnson}

$\mathrm{T}$

he CUA was saddened to learn of the passing of Dr. Edward Lee Johnson this past February at the age of 86 . He is predeceased by his wife of 56 years, Alice, and is survived by his children, Bruce, Tammy, Allison, and Lance, and grandchildren, Joshua, Amber, Aidan, Derek, Jonathan, and Jared, as well as the many members of his extended family.

Born in the small town of Lindsborg, Kansas, he grew up on a farm, where he would help with the harvest during his medical school training at Kansas University. After graduation, he completed a five-year surgical residency, followed by a urological fellowship at Tulane, finally establishing a private practice in surgical urology in Albuquerque, New Mexico. Although he retired his private practice in 2002, Dr. Johnson continued teaching at the VA Hospital until the age of 75.

Dr. Johnson would say he lived a full life and had experiences of which he could not have dreamed as a small town farm boy. He was known for being able to fall asleep in the middle of his own conversation, yet always having the energy for an adventure and the work ethic and compassion to help and care for others without obligation. He volunteered medical services for several sports teams and was instrumental in bringing professional hockey to New Mexico. Believing in the importance of always giving back to his profession, he documented data from his private practice to advance prostate cancer research. He also served a term as President of the South Central Section of the AUA.

He will no doubt be missed by family, friends, and colleagues. 